\title{
Analisis Wacana Kritis Teun A. Van Djik Terhadap Pidato Gubernur Anies Baswedan Tentang Ungkapan Kata "Pribumi"
}

\author{
Andi Tamrin \\ Universitas Islam Negri Sunan Kalijaga Yogyakarta \\ email: andielpusui93@gmail.com
}

\begin{abstract}
Media is a strategic tool to help people know information. Media is also a tool used to do politk, often the politics are trapped in the media itself (the media backfires), as in Anies Baswedan's speech when he was inaugurated as Governor of Jakarta. Where he uttered native words in his first political speech as Governor. Before he clarified the native words, he quickly expanded his speech about the native word in the ears of Jakarta residents in particular and Indonesia in general. it is known that the prohibition of using indigenous words as contained in Law No. 40 of 2008 on the elimination of discrimination and ethnicity, in addition to the Act, is also regulated in the Presidential Instrument Number 26 of 1998 on terminating the use of indigenous and non-"Pribumi" terms in all formulation and implementation of policy or activity execution governance. The research method used is Teun A. Van Djik's critical discourse analysis approach, the study of the structure of language choice and the language used. From the analysis of the critical discourse of Teun A. van Djik to governor Anies Baswedan's speech about the expression of the "Pribumi" word. Governor Anie Baswedan discusses the history of Indonesia colonized by the colonialists, with the aim giving new enthusiasm to the people of Jakarta together, so that the peole of Jakarta can provide convenience for Governor Anies Baswedan in carrying out promises when Campaining.
\end{abstract}

Keyword: Critical discourse analysis Teun A. Van Djik,
speech 


\begin{abstract}
Abstrak
Media adalah alat strategis untuk membantu manusia mengetahui sebuah informasi telah terjadi dimanapun terjadi. Media juga sebagai alat yang dijadikan untuk melakukan politk, sering kali para politik terjebak dalam media itu sendiri (media menjadi bumerang), seperti yang terdapat pada pidato Anies Baswedan saat setelah dilantik sebagai Gubernur Jakarta. Dimana ia mengucapkan kata-kata "Pribumi" dalam pidato politik pertamanya sebagai Gubernur. Sebelum ia mengklarifikasi kata "Pribumi", dengan cepat berkembang pidatonya tentang kata "Pribumi" ditelinga warga Jakarta khususnya dan indonesia umumnya. diketahui larangan memakai kata "Pribumi" sebagaimana terdapat dalam UU No 40 tahun 2008 tentang penghapusan diskriminasi dan Etnis, selain UU tersebut, hal ini juga diatur dalam instrksi Presiden Nomor 26 tahun 1998 tentang menghentikan penggunaan istilah "Pribumi" dan non"Pribumi" dalam semua perumusan dan penyelenggaraan kebijakan ataupun pelakasanaan kegiatan penyelenggaraan pemerintahan. Adapun metode penelitian yang digunakan adalah pendekatan analisis wacana kristis Teun A. Van Dijk, studi tentang struktur pilihan bahasa dan gramatika bahasa yang dipakai. Dari hasil analisis wacana kritis Teun A. Van Djik terhadap pidato Gubernur Anies Baswedan tentang ungkapan kata "Pribumi" Gubernur Anies Baswedan membacarakan historis Indonesia yang dijajah oleh kolonialis, dengan tujuanmemberikan semangat baru kepada masyarakat Jakarta untuk sama-sama membangun Jakarta, sehingga masyarakat Jakarta dapatmemberikan kemudahan untuk Gubernur Anies Baswedandalam menjalankan janji-janji ketika berkampanye.
\end{abstract}

\title{
Kata kuci: Analisis Wacana Kritis Teun A. Van Djik, Pidato dan "Pribumi"
}

\section{A. Pendahuluan}

Dewasa ini wacana dan analisis wacana memiliki peranan yang penting dalam kehidupan sosial masyarakat. Menurur Van dijk, Analisis wacana kritis adalah analis wacana yang mempertimbangkan kontek dari 
wacana, seperti latar, situasi, peristiwa, dan kondisi. Wacana disini dipandang diproduksi, dimengerti, dan dianalisis ada suatu konteks tertentu. Wacana sendiri merupakan wujud komunikasi verbal. Dari segi bentuk, wacana dibagi menjadi dua, yakni wacana lisan dan wacana tulis. Wacana lisan merupakan wujud komunikasi lisan yang melibatkan penutur dan lawan tutur, sedangkan wacana tulis merupakan wujud komunikasi tulis yang melibatkan penulis dan pembaca. Aktivitas penutur (pembicara/penulis) bersifat produktif, ekspresif, kreatif, sedangkan aktivitas lawan tutur (pendengar/ pembaca) bersifat reseptif (Sudaryat, 2009:106). Wacana dapat dikemas dengan berbagai maksud oleh penutur kepada lawan tutur. Penutur baik lisan maupun tulisan memiliki keleluasaan menyampaikan berbagai macam bentuk opini, pendapat, ataupun pikiran lewat wacana.

Permainan olah wacana sering ditargetkan untuk dikonsumsi oleh orang banyak. Oleh karena itu media massa merupakan sarana yang paling efektif untuk menyampaikan informasi yang dikemas dalam bentuk wacana ke hadapan publik, baik oleh individu, kelompok, maupun instansi pemerintah. Salah satu media massa yang kehadirannya tidak lagi dapat dipisahkan dengan masyarakat adalah televisi. Televisi yang sifatnya audio visual menawarkan kesempurnaan kepada masyarakat untuk memuaskan hasrat masyarakat dalam mendapat berbagai hiburan dan informasi. Televisi beserta dengan program-program yang ditawarkan merupakan tempat yang strategis bagi berbagai kelompok sosial dan politik untuk tampil dengan olahan bahasa yang mereka kembangkan sendiri. Kemungkinan sangat terbuka bagi kelompokkelompok tertentu dalam menampilkan definisi situasi, atau definisi realitas, versi mereka.

Dengan adanya media sebagai alat strategis untuk berpolitk, sering kali para politik terjebak dalam media itu sendiri (media menjadi bumerang), seperti yang terdapat pada pidato Anies Baswedan saat setelah dilantik sebagai Gubernur Jakarta. Dimana ia mengucapkan kata-kata "Pribumi" dalam pidato politik pertamanya sebagai Gubernur. Sebelum ia 
mengklarifikasi kata "Pribumi", dengan cepat berkembang pidatonya tentang kata "Pribumi" ditelinga warga Jakarta khususnya dan indonesia umumnya.

Perlu diketahui larangan memakai kata "Pribumi" sebagaimana terdapat dalam UU No 40 tahun 2008 tentang penghapusan diskriminasi dan Etnis, selain UU tersebut, hal ini juga diatur dalam instrksi Presiden Nomor 26 tahun 1998 tentang menghentikan penggunaan istilah "Pribumi" dan non"Pribumi" dalam semua perumusan dan penyelenggaraan kebijakan ataupun pelakasanaan kegiatan penyelenggaraanpemerintahan. (Megapolitan.kompas.com/read/2017/10/17/10145721/ternyata-ada-uu-daninpres-yang-larang-penggunanaan-kata-"Pribumi",diakses pada tanggal 10 Agustus 2019)

Berdasar latar belakang dari penelitian yang akan dilakukan seperti yang dikemukakan diatas, sehingga penulis tertarik untuk meneliti "Analisis Wacana Kritis Teun A. Van Djik terhadap Pidato Anies Baswedan Tentang Ungkapan Kata "Pribumi"

\section{B. Metode Penelitian}

Penelitian ini menggunakan metode penelitian deskriftif kualitatif (Arikunto, 2006: 54). Penelitian ini menggunakan pendekatan analisis kritisis Teun A.Van Djik.

Analisis wacana kritis adalah studi tentang struktur pilihan bahasa dan gramatika bahasa yang dipakai. Analisis wacana kritis adalah melihat bagaimana gramatika bahasa membawa posisi dan makna ideologi tertentu. Dengan kata lain, aspek ideologi itu diamati dengan melihat pilihan bahasa dan struktur tata bahasa yang dipakai(Eryanto, 2015: 15). Bahasa, baik pilihan kata maupun struktur gramatika, dipahami sebagai pilihan, mana kata yang dipilih oleh seseorang untuk diungkapkan membawa makna ideologi tertentu. Bahasa adalah suatu sistem kategorisasi, dimana kosakata tertentu dapat dipilih yang akan menyebabkan makna tertentu. 
Berikut ini karakteristik penting dari analis wacana kritis, bahan yang diambil untuk menganalisis suatu wacana dari tulisan Teun A. Van Dijk (Eryanto, 2015: 15). 1) Tindakan,Prinsip pertama, wacana dipahami sebagai sebuah tindakan (aktion). Dengan pemahaman semacam ini mengasosiasikan wacana sebagai bentuk interaksi. Wacana bukan ditempatkan seperti dalam ruang tertutup dan internal. 2) Konteks, Analisis wacana kritis mempertimbangkan kontek dari wacana, seperti latar, situasi, peristiwa, dan kondisi. Wacana disini dipandang diproduksi, dimengerti, dan dianalisis ada suatu konteks tertentu. 3) Historis,menempatkan wacana dalam konteks tertentu, berarti wacana diproduksi dalam konteks tertentu dan tidak dapat dimengerti tanpa menyertakan konteks yang menyertainya. Salah satu aspek penting untuk bisa mengenai teks adalah dengan menempatkan wacana itu dalam konteks historis tertentu. 4) Kekuasaan,Analisis wacana kritis juga mempertimbangkan elemen kekuasaan dalam analisnya. Setiap wacana yang muncul, dalam bentuk teks, percakapan atau apapun, tidak dipandang sesuatu yang alamiah, wajar dan netral tetapi merupakan bentuk pertarungan kekuasaan. Konsep kekuasaan adalah salah satu kunci hubungan antara wacana dengan masyarakat.

\section{a. Ideologi}

Ideologi juga konsep yang sentral dalam analisis wacana yang bersifat kritis. Hal ini karena teks, percakapan, dan lainnya adalah bentuk dari praktik ideologi atau cerminan dari ideologi tertentu. Bagi Barthes teks adalah sebuah objek kenikmatan, kesenangan kala menyusuri halaman demi halaman objek yang dibaca (Alex Sobur, 2002: 52).

Analisis wacana Van Dijk melihat penelitian analisis wacana tidak hanya didasarkan pada analisis atas teks semata. Selain daripada teks semata. Selain daripada teks, perlu dilihat pula bagaimana suatru teks diproduksi, sehingga dapat diketahui bagaimana teks bisa seperti itu. Model yang sering digunakan dalam penelitian adalah model analisis wacana Van Dijk. Hal ini dikarenakan model Van Djik adalah model paling lengkap 
karena mengelaborasi elemen-elemen wacana sehingga dapat digunakan secara praktis. Model Van Djik ini sering disebut kognisi sosial(Eryanto, 2015: 225).

Wacana oleh Van Djik digambarkan mempunyai tiga dimensi (bangunan), yaitu: teks, kognisi sosial, dan konteks sosial. Inti dari model ini adalah menggabungkan ketiga dimensi wacana tersebut ke dalam satu kesatuan analisis. Analisis model Van Djik melihat bagaimana struktur sosial, dominasi, dan kelompok kekuasaan yang ada dalam masyarakat dan bagaimana kognisi (pikiran) dan kesadaran yang membentuk dan bepengaruh terhadap teks tertentu.

Dimensi teks meneliti bagaimana struktur teks serta strategi wacana yang dipakai untuk menegaskan tema tertentu. Sedangkan tahap kognisi sosial diteliti terkait proses produksi teks yang melibatkan kognisi individu dari penyampai pesan. Sedangkan aspek ketiga yakni mempelajari bangunan wacana yang berkembang dalam masyarakat akan suatu persoalan.

\section{Gambar 1: Model dari Analisis Van Djik}

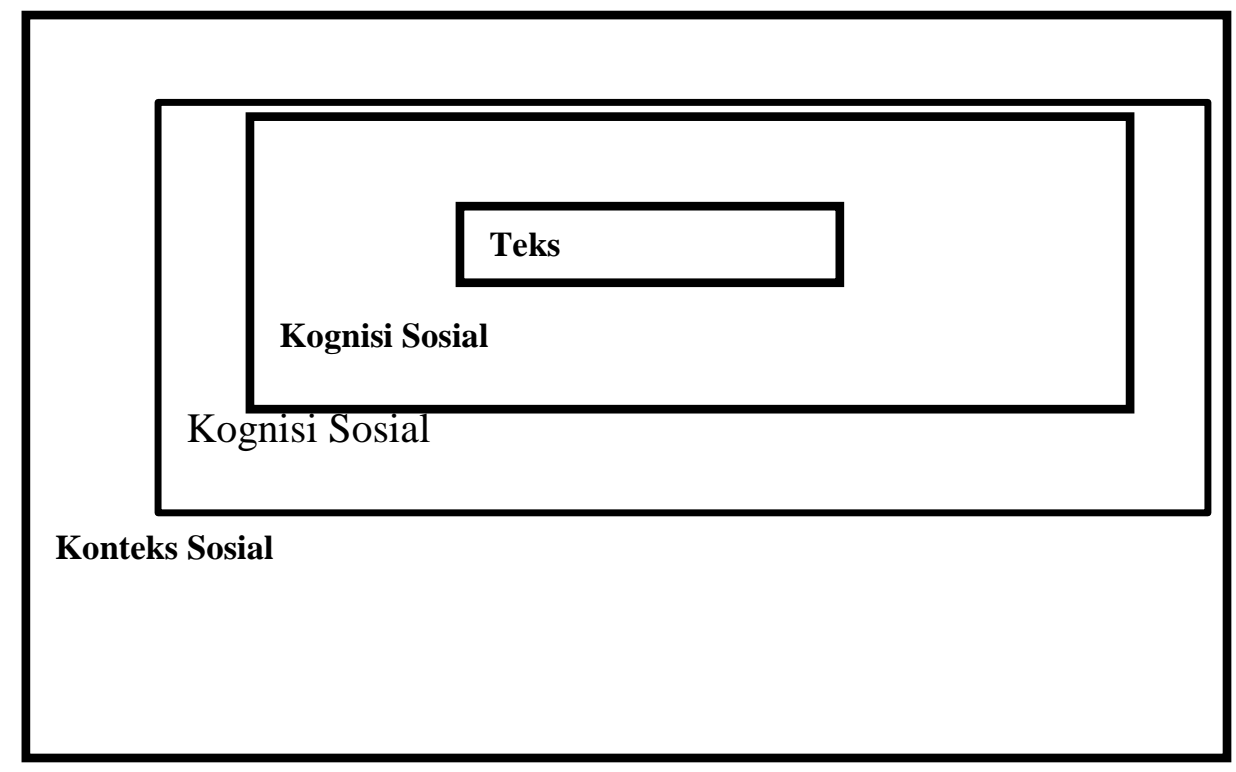


Gambar 2: Struktur (elemen) wacana yang dikemukakan Van Dijk

\begin{tabular}{|c|}
\hline Struktur Makro \\
Makna global dari suatu teks yang dapat diamati dari topik (tema) \\
yang diangkat oleh suatu teks
\end{tabular}

Gambar 3: Struktur analisis Van Djik:

\begin{tabular}{|c|c|c|}
\hline Struktur Wacana & Hal yang Diamati & Elemen \\
\hline Struktur Makro & $\begin{array}{l}\text { Tematik } \\
\text { Tema (topik) yang } \\
\text { diutamakan dalam suatu } \\
\text { berita }\end{array}$ & Topik \\
\hline Superstruktur & $\begin{array}{l}\text { Skematik } \\
\text { Bagaimana bagian dan } \\
\text { urutan berita } \\
\text { diskemakan dalam teks } \\
\text { berita utuh }\end{array}$ & Skema \\
\hline Struktur Mikro & $\begin{array}{l}\text { Semantik } \\
\text { Makna yang ditekankan } \\
\text { dalam teks berita. } \\
\text { Misalnya dengan } \\
\text { memberi detail pada } \\
\text { satu sisi dan }\end{array}$ & $\begin{array}{l}\text { Latar, detail, } \\
\text { maksud, pra- } \\
\text { anggapan, } \\
\text { nominalisasi }\end{array}$ \\
\hline
\end{tabular}




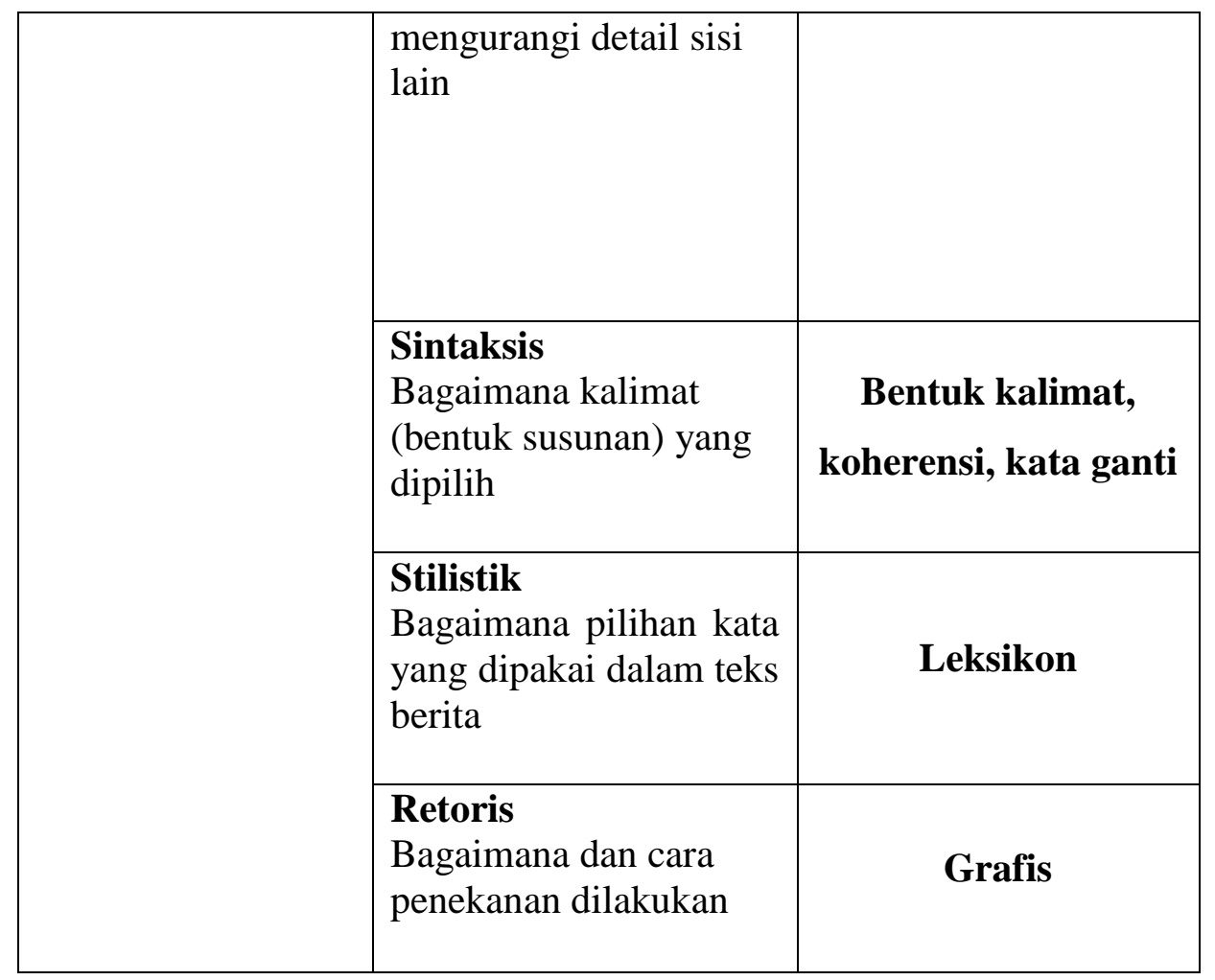

\section{C.Pembahasan}

Dalam penelitian ini penulis menggunakan konsep teori sebagai berikut:

\section{C.1 Komunikasi Massa}

komunikasi massa diadopsi dari istilah bahasa inggris, mass communication, sebagai kependekan dari mass media communication. Artinya, komunikasi yang menggunakan media massa atau komunikasi yang mass mediated. Istilah mass cominication atau communication sebagai saluranya, yaitu media massa (mass media) sebagai kependekan dari media of mass comunication. Massa mengandung pengertian orang banyak, mereka tak harus berada di lokasi, yang dalam waktu yang sama, atau hampir bersamaan dapat memperoleh pesan-pesan komunikasi yang sama (Ngalimun, 2017: 90). 
Organisasi-organisasi ini akan menyebarluaskan pesan-pesan yang memengaruhi dan mencerminkan kebudayaan suatu masyarakat, lalu informasi akan mereka hadirkan serentak pada khalayak luas yang beragam. Hal ini membuat media menjadi bagian dari salah satu institusi yang kuat di masyarakat.

Sedangkan media massa sering disingkat jadi "media", saja adalah saluran, sarana, atau alat yang digunakan dalam proses komunikasi massa, yakni komunikasi yang diarahakan kepada orang banyak.

Berdasarkan teori di atas, penulis akan menjelaskan bahwa dengan media sebagai saluran yang bersifat fisik, seperti media cetak atau media elektronik yang akan menjadi sumber informasi dalam pembahasan ini.

\section{C.2 Nasionalisme dan "Pribumi".}

Nasionalisme itu adalah suatu itikad, suatu keinsyafan rakyat, bahwa rakyat itu ada suatu golongan, suatu bangsa (Soekarno, 2012: 12). Nasionalisme juga adalah suatu sikap politik dari masyarakat suatu bangsa yang mempunyai kesamaan kebudayaan, dan wilayah serta kesamaan citacita dan tujuan, dengan demikian masyarakat suatu bangsa tersebut merasakan adanya kesetiaan yang medalam terhadap bangsa itu sendiri.

Demikian juga ketika berbicara tentang nasionalisme. Nasionalisme merupakan jiwa bangsa Indonesia yang akan terus melekat selama bangsa Indonesia ini masih ada. Nasionalisme bukanlah suatu pengertian yang sempit bahkan mungkin masih lebih kaya lagi pada zaman ini.

Kata "Pribumi" dalam Kamus Besar Bahasa Indonesia " "Pribumi"”, artinya penghuni asli yang berasal dari yang bersangkutan. Jadi "Pribumi" adalah setiap orang yang lahir disuatu tempat, wilayah atau negara, dan menetap disana dengan status orisinal, asli atau tulen sebagai kelompok etnis yang diakui sebagai suku bangsa bukan pendatang dari negeri lainnya.

Terkait dengan pidato politik Gubernur Anies Baswedan, ia berbicara masa kolonial Belanda, "Pribumi" dipakai sebagai istilah melayu untuk inlanders, salah satu kelompok penduduk Hindia Belanda yang 
berasal dari suku-suku asli kepulauan Nusantara. Dalam pidato itu, ia hanya berbicara dalam kontek sejarah dan nasionalisme bangsa indonesia agar lebih mencintai bangsa Indonesia pasca kemerdekaan. Karena para pendahulu telah memperjuangkan kemerdekaan negara Indonesia dengan pertumbahan darah, harta, dan jabatan demi kemerdekaan.

Gubernur Anies Baswedan hanya membicarakan nasionalisme dalam pidatonya, agar semua bangsa Indonesia dan khususnya Jakarta agar mencintai dan menghargai perjuangan para pahlawan-pahlwan Republik Indonesia.

Dalam penelitian ini, peneliti mengunakan pendekatan analisis wacana model Teun A. Van dijk dengan menggunakan tiga elmen yaitu, analisis dari segi teks, kognisi sosial, dan kontek sosial (Eryanto, 2015: 229).

\section{C.3 Analisis wacana kritis pidato Anies Rasyid Baswedan}

Berdasarkan teori komunikasi massa dan media di atas, penulis mengambil referensi dari buku dan selain itu penulis juga mengambil referensi yang ada di media seperti Bbc.com, Liputan6.com dan Jawapost sebagai landasan untuk menjabarkan analisis wacana kritis tentang pidato Anies Baswedan saat dilantik sebagai Gubernur jakarta. Sebagaimana yang dijelaskan dibawah ini.

\section{a. Struktur Makro (tematik)}

Dalam teori Van Dijk, tema merupakan struktur makro tingkatan analisis pertama. Tema mengisyaratkan intisari dari sesuatu dan dalam konteks penelitian peneliti adalah pidato Anies Rasyid Baswedan saat setelah dilantik menjadi gubernur DKI Jakarta. Topik ini juga akan membantu menganalisis dalam pidato, karena tidak mungkin dapat dipahami teks secara global tanpa topik utama. Bahasa mewakili konteks suatu teks untuk dianalisis. 
Tematik yang terdapat dalam pidato Anies Baswedan setelah dilantik menjadi gubernur DKI Jakarta "komitmen bangun Jakarta" namun dalam isi pidatinya ada kata yang menjadi kontroversi sehingga membuat sebagian orang mengkritik pidato tersebut, yakni ".dulu kita semua "Pribumi" ditindas dan dikalahkan. Kini saatnya menjadi tuan rumah di negeri sendiri (http://m.liputan6.com/news/read/3130861/pidato-lengkap-aniesbaswedan-setelah-dilantik-jadi-gubernur-dki,diakses pada tanggal 14 Agustus 2019)

Dalam pidato Anies Baswedan tentang kata "Pribumi" menggambarkan konteks sejarah Indonesia. Secara histori bangsa Indonesia yang pernah dijajah ratusan tahun oleh kolonialis. Kata "Pribumi" ini ditujukan kepada rakyat asli Indonesia yang khususnya bertempat tinggal di Jakarta.

\section{b. Superstruktur (semantik)}

Superstruktur dalam penelitian ini akan menganalisis terkait pendahuluan, isi, penutup, dan kesimpulan dalam wacana dari keseluruhan segmen. Elemen atau tingkatan selanjutnya yang patut diteliti dalam teori Van dijk adalah skema, kerangka atau alur suatu pidato. Dalam hal ini perlu dijabarkan atau digambarkan bagaimana alur dalam suatu pidato tersusun sedemikian rupa. Kerangka atau alur tersebut akan digambarkan bagianbagian ataupun pola-pola dari pidato yang disusun dan diurutkan sehingga membentuk kesatuan arti atau makna. Alur dari suatu skema dalam pidato ini memiliki bentuk beragam.

Pada bagian pendahuluan Anies Baswedan mengucapkan bentuk rasa syukur kepadan Tuhan Yang Maha Kuasa atas terpilihnya sebagai gubernur Jakarta. Ucapan rasa syukur itu juga ia sampaikan kepada seluruh warga Jakarta atas kepercayaan memimpin Jakarta lima tahun kedepan. Ini adalah ekspresi rasa syukurnya kepada Allah SWT.

“..warga Jakarta telah bersuara dan telah terpaut dalam sebuah rasa yang sama yaitu keadilan bagi semua. Maka 
dengan mengucap syukur dan do'a kepada Allah SWT yang Maha Penolong, yang Maha Melindungi, Alhamdulillah sebuah fase telah di lewati.."

Pada bagian isi Anies baswedan menjelaskan bagaimana cara menciptakan persatuan dan kesatuan warga Jakarta, mengajak tanpa memandang latar belakang, etnis, suku, ras dan agama. Jakarta adalah pusat berkumpulnya berbagai manusia dari seluruh nusantara. Anies Baswedan menyampaikan akan menghadirkan keadilan sosial bagi seluruh rakyat Indonesia, menjalin tali persatuan, merangkul yang lemah, mencerdaskan warga Jakarta, dan komitmen bangun Jakarta.

Peneliti memandang bahwa Gubernur Anies Baswedan berupaya mengingatkan kembali janji-janjinya ketika kampanye di tengah-tengah warga Jakarta. Ia ingin fokus membangun Jakarta bersama-bersama dengan warga Jakarta, seperti yang terdapat dalam pidatonya:

“..untuk itu, izinkan kami mengajak seluruh warga menjadikan
usaha, memajukan kota sebagai sebuah gotong royong, sebagai
sebuah gerakan, pembangunan kota ke depan, gubernur bukan
sekedar administrator bagi penduduk kota. Gubernur bukan
sekadar penyedia jasa bagi warga yang jadi konsumen namun
kami bertekad untuk bisa melakukan lebih dari itu. Kami ingin
bisa bekerja bersama dengan warga Jakarta, berkolaborasi
dengan warga Jakarta sebagai perancang dan pelaku
pembangunan..."

Dalam isi pidato Gubernur Anies Baswedan menjelaskan sejarah negara Indonesia pada zaman dulu dalam konteks Jakarta. Sebagai bangsa, Indonesia memiliki sejarah yang kelam, Indonesia pernah dijajah oleh kolonialis, terkhusus di ibu kota Jakarta sangat terasa atas penjajahan itu oleh kolonialis. Dimana warga Jakarta ditindas, dan pada saat itulah warga asli Indonesia disebut sebagi "Pribumi", seperti yang tercantum dalam pidato Anies Baswedan. 
“...dulu kita semua "Pribumi" ditindas dan dikalahkan, kini kita telah merdeka, kini saatnya menjadi tuan rumah di negeri sendiri..”

Pada bagian penutup, Anies Baswedan menyampaikan kelemahannya sebagai hamba yang dho'if yang tak berdaya, supaya Allah SWT senantiasa selalu memberikan pertolongan atas ikhtiar yang selalu diperbuat oleh seluruh warga Jakarta. Seperti terdapat dalam pidatonya:

“...dengan memohon pertolongan kapada Allah Yang Maha Memberi Pertolongan, mari kita bersama beriktiar mewujudkan Jakarta yang maju setiap jengkalnya, dan bahagia setiap insan di dalamnya. Semoga Allah SWT membantu ikhtiar kita..."

Pada bagian kesimpulan, peneliti menyimpulkan bahwa pidato Anies Baswedan mengajak kepada seluruh warga Jakarta untuk menjadi perancang, pengawal, dan pelaku pembangunan. Merajut berdasarkan ketuhanan, kemanusia, persatuan, yang berkerakyatan dan berkeadilan sosial bagi seluruh rakyat Indonesia.

\section{c. Analisis Struktur Mikro}

Analisis wacana kritis dalam pidato Anis Baswedan saat setelah dilantik menjadi Gubernur Jakartaini yang akan dianalisis dari struktur mikro. Analisis struktur mikro mengamati secara mendalam terkait makna (semantik), penataan kalimat (sintaksis), pilihan kata (leksikon) dan grafis (retoris).

\section{1) Semantik}

Van Dijk mengkategorikan skema sebagai makna lokal (lokal meaning) yaitu makna yang muncul dari hubungan antar proposisi, yang membangun makna tertentu dari suatu pidato. Analisis wacana terutama memusatkan perhatian pada dimensi pidato, seperti makna yang eksplisit maupun implisit. Latar adalah bagian teks yang dapat mempengaruhi 
semantik (arti) yang ingin ditampilkan. Latar ini kemudian menentukan kearah mana pandangan masyarakat hendak dibawa. Latar umumnya ditempilkan di awal sebelum mendapat komunikator yang sebenarnya muncul dengan maksud mempengaruhi dan memberi kesan bahwa pendapat komunikator atau teks sangat beralasan.

Latar yang menjadi akar permasalah dalam pidato Gubernur Anies Baswedan terdapat pada kata "“Pribumi"” seperti yang terdapat dalam pidatonya:

\section{“...dulu kita semua "Pribumi" ditindas dan dikalahkan. Kini telah merdeka, kini saatnya menjadi tuan rumah di negeri sendiri.."}

Kata "Pribumi" dalam Kamus Besar Bahasa Indonesia " "Pribumi"," artinya penghuni asli yang berasal dari yang bersangkutan. Dalam hal ini pidato Gubernur Anies Baswedan yang menjelaskan kata "Pribumi" itu konteksnya sejarah, sejarah kelam bangsa Indonesia ratusan tahun dijajah oleh kolonialis ( https://kbbi.web.id/"Pribumi".html,diakses pada tanggal 20 Agustus 2019).

Menurut peneliti kata "Pribumi" dalam pidato Anies Baswedan memiliki arti bahwa jangan sesekali melupakan sejarah seperti yang pepatah Ir. Soekarno "jangan sesekali melupakan jas merah" karena ia berbicara dalam konteks sejarah. Dengan sejarah, warga Jakarta tahu bagaimana arti dari perjuangan.

Dari kata "Pribumi" ini, melahirkan persepsi-persepsi dari warga Jakarta, baik yang pro maupun yang kontra khususnya dari masyarakat intelek dan masyarakat Indonesia umumnya. Karena kata "Pribumi" ini sudah jelas dilarang dipakai, baik itu dalam pemerintahan, kampanye dan pidato politik, sebagaimana terdapat dalam UU No 40 tahun 2008 tentang penghapusan diskriminasi dan Etnis, selain UU tersebut, hal ini juga diatur dalam instrksi Presiden Nomor 26 tahun 1998 tentang menghentikan penggunaan istilah "Pribumi" dan non"Pribumi" dalam semua perumusan 
dan penyelenggaraan kebijakan ataupun pelakasanaan kegiatan penyelenggaraan pemerintahan.

\section{2) Sintaksis}

Analisis sintaksis adalah analisis yang berkaitan dengan susunan dan penataan kalimat penutur. Susunan dan penataan kalimat ini diramu sebaik mungkin dengan harapan tujuan dan sasaran yang diinginkan dapat dicapai. Berikut akan disajikan pidato Gubernur Anies Baswedan dalam lingkup sintaksis.

Pemilihan kata ganti merupakan elemen untuk memanipulasi bahasa dengan menciptkan suatu komuntas imajinatif. Kata ganti merupakan alat yang dipakai oleh komunikator untuk menunjukkan dimana posisi seseorang dalam wacana. Dalam mengungkapkan sikapnya, seseorang dapat menggunakan kata ganti "saya"atau "kami" yang menggambarkan bahwa sikap tersebut merupakan sikap resmi dari komunikator semata.

Dalam pidato Anies Baswedan yang berjudul "Komitmen Bangun Jakarta" lebih fokus kepada kata “...Dulu kita semua "Pribumi” ditindas dan dikalahkan. Kini telah merdeka, kini saatnya menjadi tuan rumah di negeri sendiri..".

Dalam pidato tersebut terdapat kata ganti "saya" menjadi "kita", maka ketika Gubernur Anies Baswedan memakai kata ganti "kami" menunjukkan sikap tersebut sebagai representasi dari sikap bersama dalam suatu komunitas atau seluruh warga Jakarta. Karena pemakaian kata "kita" mempunyai implikasi menumbuhkan solidaritas, aliansi, perhatian publik, serta mengurangi kritik dan oposisi hanya kepada diri sendiri.

Artinya bahwa Gubernur Anies Baswedan dalam pidatonya berbicara kepada para tamu undangan khususnya dan umumnya kepada seluruh warga Jakarta. Dengan memakai kata ganti "kita" seolah-olah apa yang disampaikannya dalam pidato adalah urusan bersama warga Jakarta bukan urusan seorang Gubernur dan Wakil Gubernur saja. 


\section{3) Stilistik}

Kajian stilistik dalam analisis wacana kritis adalah kajian tentang pilihan kata yang digunakan komunikator dalam menyampaikan pesan, maksud, dan ideologinya. Oleh karena itu analisis stilistik (pemilihan kata) dalam penelitian ini akan melihat bagaimana maksud pemilihan kata digunakan oleh seorang komunikator.

Pemilhan kata pidato Gubernur Anies Baswedan dalam stilistik ini lebih merujuk kepada kata-kata "“Pribumi”" seperti tercantum pada pidatonya "dulu kita semua "Pribumi" ditindas dan dikalahkan. Kini telah merdeka, kini saatnya menjadi tuan rumah di negeri sendiri.."

Dalam Kamus Besar Bahasa Indonesia (KBBI) kata “"'Pribumi”" adalah penghuni asli; yang berasal dari tempat yang bersangkutan. Anies Baswedan menggambarkan "Pribumi" dilawankan atau diaposisikan dengan penjajah yang berkenaan dengan sejarah kolonialisme di Jakarta pada masa silam. Ia menambahkan, pemakaian kata ““'Pribumi”"” berupa konteks kebahasaan. Dalam ilmu Bahasa konteks merupakan kalimat-kalimat yang dating sebelum dan beberapa saat setelah kata "“Pribumi"” itu dipakai ketika ia berbicara tentang Jakarta sebagai ibu kota yang telah dihuni masyarakat ("Pribumi") yang pernah dijajah oleh kolonialis (penjajah) hingga merdeka. Jadi, kata ““"Pribumi”" yang digunakan oleh gubernur Jakarta Anies Baswedan itu merujuk pada masyarakat Jakarta yang dijajah oleh kolonialis pada masa kolonialisme(https://www.goole.co.id/search?q=ungkapan+yang=terdapat +pada+ "Pribumi" \& client=ms-diakses pada tanggal 22 Agustus 2019)

Gubernur Anies Baswedan berbicara tentang sejarah dan juga tentang nasionalisme bangsa Indonesia, ia mengingatkan masyarakat Jakarta bangsa untuk menjaga kebhinnekaan dan pancasila sebagai dasar negara. Ia mengajak kepada masyarakat Jakarta untuk menjaga kesatuan bangsa danmenghargai, mencintai jasa-jasa perjuangan para pahlawan untuk merebut kemerdekaan. Dari pidatonya, ia mengajak dan menanamkan rasa, 
sikap nasionalisme pada warga Jakarta, untuk sama-sama menjaga keutuhan Pancasila.

Adapun bentuk susunan kata "Pribumi" dihimpit oleh penjelasan konteks sejarah, dimana sebelum kata "Pribumi", ada kalimat sebelumnya yang menjelaskan histori bangsa Indonesia. Anies Baswedan menjelaskan dan memberikan klarifikasi isi pidato politik pertamanya tersebut. Ia mengatkan, Jakarta adalah kota yang paling dekat dengan penjajahan saat kolonialisme masih berkuasa di negeri ini. Dalam konteks itulah pernyataan "Pribumi" harus dipahami.

"kalau kota lain itu enggak lihat Belanda dari dekat. Yang lihat Belanda dari jarak dekat siapa? Orang jakarta, coba kita di pelosok Indonesia, tahu ada Belanda tapi lihat depan? Enggak, jadi yang lihat (penjajah) depan mata itu orang Jakarta.."

Data-data yang telah dianalisis dari berbagai macam perbandingan pilihan kata yang sepadan dengan kata lain. Adapun pilihan kata yang digunakan dalam pidato tersebut adalah kata “"Pribumi"” jelas ia berbicara dalam konteks sejarah. Dan kata"“Pribumi"” ini sudah barang tentu, ada pihak-pihak kurang sependapat dengan pidato tersebut.

\section{4) Retoris}

Kajian retoris dalam analisis wacana kritis Van Dijk, menganalisis hal terkait dengan grafis, metapora dan ekpresi. Dalam penelitian inihal yang di kaji dari ketiga poin tersebut adalah lingkup metafora. Berikut akan disajikan analisis data yang berkaitan dengan metofora.

“...dulu kita semua "Pribumi" ditindas dan dikalahkan. Kini telah merdeka, kini saatnya menjadi tuan rumah di negeri sendiri. Jangan sampai Jakarta ini seperti yang dituliskan pepatah Madura. Itik telor, ayam singerimi. Itik yang bertelor, ayam yang mengerami.." 
Ungkapan atau kiasan yang terdapat dalam pidato Gubernur Anies Baswedan dalah kata ungkapan "“Pribumi”" ia mengibaratkan dengan pepatah Madura "itik telor, ayam singerimi. Itik yang bertelor, ayam yang ngerami.." maksudnya kita yang bekerja keras untuk merebut kemerdekaan. Kita yang bekerja keras untuk mengusir kolonialisme. Kita semua harus merasakan manfaat kemerdekaan di ibu kota ini. Dan kita menginginkan Jakarta bisa menjadi layaknya sebuah arena aplikasi Pancasila. Dari metafora (ungkapan) daiatas Gubernur Anies Baswedan ingin memunculkan suasana yang halus namun dengan maksud yang tajam. Artinya pendengar bisa saja menangkap katanya dengan halus, namun tidak begitu dengan maknanya.

\section{Penutup}

Dari hasil penelitian analisis wacana kritis model Teun A. Van Dijk dalam pidato Gubernur Anies Baswedan dapat penulis simpulkan sebagai berikut: Pertama berkaitan dengan analisis struktur makro, superstruktur dan struktur mikro. Analisis ini berkaitan dengan tema besar yang diangkat dalam pidato. Struktur-struktur ini menunjuk pada makna keseluruhan maupun makna khsus yang dapat dicermati dari tema yang diangkat oleh pemakaian bahasa ketika be dalam suatu suatu amalis wacana kritis. Gubernur Anies Baswedan membacarakan historis Indonesia yang dijajah oleh klonialis, dengan memberikan semangat baru kepada masyarakat Jakarta untuk sama-sama membangun Jakarta, sehingga masyarakat Jakarta memberikan kemudahan untuk Gubernur Anies Baswedan bekerja demimenjalankan janji-janji kampanye politiknya. Kedua: Terkait dengan kata "Pribumi", bahwa pemakaian kata "Prbumi" tidak diperbolehkan dalam suatu kegiatan penyelenggara pemerintahan atau dalam orasi politik sesuai UU yang berlaku.Namun kata "Pribumi"pada pidato Anies Baswedan, tidak sama dengan kata-kata yang "Pribumi" yang berlaku pada penghinaan 
rasatau suku sesuai yang berlaku menurut undang-undang,dikarenakan katakata "Pribumi"dalam pidato Anies Baswedan sesuai analisis kritis Teun A. Van Djikadalah kata yang membangkitkan rasa nasionalisme, rakyat Jakartauntuk bersama-sama membangun Jakarta.Kemudian Anies Baswedan mengajak kepada warga Jakarta untuk selalu menjaga kebehinnekaan dan pancasila. Pancasila adalah sebagai dasar negara Indonesia dan mengajak untuk menanamkan nilai-nilai kecintaan terhadap bangsa Indonesia, untuk menghargai jasa-jasa para pahlawan yang telah berjuang merebut kemerdekaan Republik Indonesia serta menjaga persatuan dan rasa keadilan sosial bagi seluruh rakyat Indonesia.

\section{Daftar Pustaka}

Arikunto, Suharsimi. 2006. Manajemen Penelitian. Jakarta: Rhineka Cipta.

Eriyanto, 2012, Analisis Framing: Kontruksi, Ideologi, dan Politik Media, Yogyakarta: PT LkiS

Eriyanto, 2015, Analisis Wacana: Pengantar Analisis Teks Media, Yogyakarta: PT LKiS

Ngalimun, 2017. Ilmu Komunikasi Sebuah Pengantar Praktis, Yogyakarta: Pustaka Baru Press

Sobur, Alex. (2009). Analisis Teks Media: Suatu Pengantar untuk Analisis Wacana, Analisis Semiotik, dan Analisis Framing. Bandung: PT RemajaRosdakarya Offset.

Soekarno, 2012. Nasionalisme, Islamisme dan Marxisme. Bantul: Kreasi Wacana

http://www.bbc.com/indonesia/trensosial-41653854

http://m.liputan6.com/news/read/3130861/pidato-lengkap-aniesbaswedan-setelah-dilantik-jadi-gubernur-dki

https://www.google.co.id/search?q=ungkapan+yang+terdapat+pada+ "Pribumi" \&client=ms 
https://www.jawapos.com/read/2017/10/17/163150/jelas-sudahbegini-klarifikasi-anies-baswedan-soal-pidato-"Pribumi" 